\title{
POPULATION FLUCTUATION OF CITRUS LEAFMINER, PHYLLOCNISTIS CITRELLA STAINTON (LEPIDOPTERA: GRACILLARIIDAE) IN THREE CITRUS VARIETIES
}

\author{
Heba M. Elnagar and M. H. A. Soliman \\ A.R.C. Plant Prot. Res. Inst., Doki, Giza, Egypt
}

Received: Oct. 3, 2016

Accepted: Oct. 18,2016

\begin{abstract}
This work was carried out in a private farm of citrus orchard sited at Minia Elkamh district, Sharkia governorate, Egypt, during two successive years 2013/2014 and 2014/2015. Selected citrus trees represented three varieties ( noval orange, sweet orange and mandarin). The aim of this study was to monitor population fluctuation of citrus leaf-miner, Phyllocnistis citrella Stainton (Lepidoptera: Gracillariidae) on noval orange, sweet orange and mandarin, as well as to know the effect of air temperature, relative humidity and dew point on population fluctuation of larvae. The obtained results revealed that number of $P$. citrella larvae /leaf were more on noval orange than sweet orange and mandarin trees. Phyllocnistis citrella populations increased during summer months and declined during fall and winter. During the study period, 4-5 peaks of pest populations recorded on the summer shoots and 1 peak on the fall and winter shoots. Statistical analysis of the obtained data show that there are positive correlation between population of P. citrella and each of temperature, relative humidity and dew point.
\end{abstract}

Key words: Phyllocnistis citrella, population fluctuation, citrus, environmental factors .

\section{INTRODUCTION}

The citrus leafminer, Phyllocnistis citrella Stainton, 1856 (Lepidoptera: Gracillariidae) is a serious pest in citrus trees of the world (Clasen,1931).This pest was first described from Calcutta, India in 1856. It attacks only the young leaves and tender (Knapp et al. , 1995). It is polyphagous and feeds primarily on citrus plants of (Fam. Rutaceae) including Aegle marmelos (L.), Aiton sp. (Fletcher 1920) and Atalania sp (Sasscer, 1915). Other reported hosts include Jasminum sambac (L.) , Loranthus spp (Reinking and Groff,1921), Murraya paniculata (L.) and Alseodophne semecorpifolia Ness( Latif and Yunus, 1951). Since 1994 this pest remains a serious problem in Egypt to citrus orchards (Knapp et al,1995). All citrus growing countries in the Mediterranean basin were invaded by this best between 1994 and 1995 ( Garcia Mari et al, 1997). Phyllocnistis citrella is a micro-lepidopteron insect which during its larval stages mines the adoxial and aboxial larvae of the pest destroy the epidermis of young leaves by mining through the leaf surfaces and the damaged leaves curl and become sclerotic and necrotic .

Heavy infestations can seriously affect plants from nurseries and recently planted trees although the damage is less significant in mature trees ( Uygun et al, 2000). The origin from eastern and southern Asia, after 1993 was rapidly spread to all citrus growing regions of America and in the Mediterranean basin. In Greece, it was first recorded in June 1995 on the island of Rhodes and in Crete (Anagnou 1995, Michelakis 1997), and within a few months, it was spread in most of the citrus growing areas of Greece (Tsagkarakis et al., 1999). Heavy infestation of $P$. citrella can severely damage young citrus trees in the field or in nurseries, while the damage is less significant in mature trees (Garcia-Marí et al., 2002).

The aim of this study was to register population fluctuation of citrus leaf-miner on noval orange, sweet orange and mandarin, in Sharkia Governorate, Egypt, during two 
successive years 2013/2014 and $2014 / 2015$, as well as the effect of air temperature, relative humidity and dew point on it.

\section{MATERIALS AND METHODS}

This work was carried out in a private farm of citrus orchard sited at Minia Elkamh district , Sharkia governorate, Egypt, during two successive years 2013/2014 and $2014 / 2015$. Selected citrus trees in moderately age for three varieties ( noval orange, sweet orange and mandarin ). The sample was 100 leaves picked up at random from each variety of citrus under field conditions. Weekly sampling were conducted from May 2013/2014 to Apr. 2014/2015. The seasonal fluctuation of Phyllocnistis citrella larvae was studied on three citrus species. Daily records of average means of air temperature, relative humidity and dew point were obtained from the Agro-meteorological station Zagazig city, Sharkia governorate which is located closely to experimental area during two successive seasons. The relationship between the weekly mean of air temperatures, mean relative humidity and mean dew point were calculated.

This orchard contained 270 noval orange trees 7 years-old, 400 sweet orange trees and 418 mandarin trees 15 years-old. No insecticides sprays were applied during the period of the study. In each sampling, five trees were randomly selected from each citrus species. The canopy of each tree was divided in two sides (north and south) and two layers (one and two meters above the ground) and one flush, contain 25 young leaves, was collected from each of these four divisions. Therefore, a total of 100 young leaves per citrus species were collected in each sample / week, which were placed into paper bags. Leaves were examined in the laboratory under a binocular stereo-microscope for presence of larvae at any age. Numbers of $P$. citrella individuals per/100 leaves were recorded. Analysis were conducted using the statistical package JMP 7.0.1 (SAS Institute, 2007).

\section{RESULTS AND DISCUSSION 1-Population fluctuation of Phyllocnistis citrella infesting noval, sweet orange and mandarin through 2013 and 2014 seasons:}

The citrus orchard was sampled for 26 times between 1, May and 17, Apr. Data in (Fig.1) show that population of Phyllocnistis citrella infesting noval orange divided into two parts during 2013 and 2014 seasons, the first part recorded the highest populations beginning from 1,May, 2013 to 14 November, 2013 and the second part from 28 Nov. 2013 till 20 Mar. 2014 recording a sharp decrease in larvae populations (zero numbers). In the same (Fig.1) it is clear that larvae population recorded 7 peaks through 2013/2014 seasons, the first peak recorded 53 larvae/ 100 leaves at 1 , May while $2^{\text {nd }}, 3^{\text {rd }}, 4^{\text {th }}, 5^{\text {th }}$, $6^{\text {th }}$ and $7^{\text {th }}$ peaks recorded $62,60,70,71,60$ and 38 larvae at 29, May,26 Jun, 7 Aug.,18 Sep., 30 Oct.2013 and 17 Apr. 2014, respectively. Temperature and relative humidity and Dew point affect on population where that temperature, relative humidity and dew point ranged between (20.92 to $29.28^{\circ} \mathrm{C}$ ), ( 35 to $\left.64.35 \mathrm{RH}\right)$ and $(7.71$ to 16.99 DP) cause increasing in population during examination periods .

Data illustrated in (Fig. 2) show that larvae population recorded six peaks on sweet orange at 2013 and 2014, respectively, at 1 May, 12 June, 7 Aug., 4 Sept., 30 Oct, 2013 and 17 April, 2014 recorded 52, 50,56,55, 41 and 15 larvae/100 leaves, respectively, where air temperature, $\mathrm{RH}$ and DP were (25.64, 46.42 and 12.64 ), ( 28.92, 39.28 and 10.99), ( 29.28, 50.64 and 16.99), (28.63, 56.21 and 18.13), (23.28, 64.35 and 13.99) and (20.92, 45.35 and 7.71), respectively. Also the number of $P$. citrella larvae on sweet orange was less than that infesting noval orange which may be due to chemical component and hardiness of cell wall. 
Results illustrated in Fig.(3) show that the population starting at 1, May 2013 then it gradually decreased until 12 June ,2013 recording 35 larvae $/ 100$ leaves, then it was gradually fluctuated between increase and decrease, recording 30 larvae at 7 , Aug., and ending by 27, 28 and 12 larvae / 100 leaves at 4, Sept. , 2, Oct. and 12 Dec. 2013, respectively

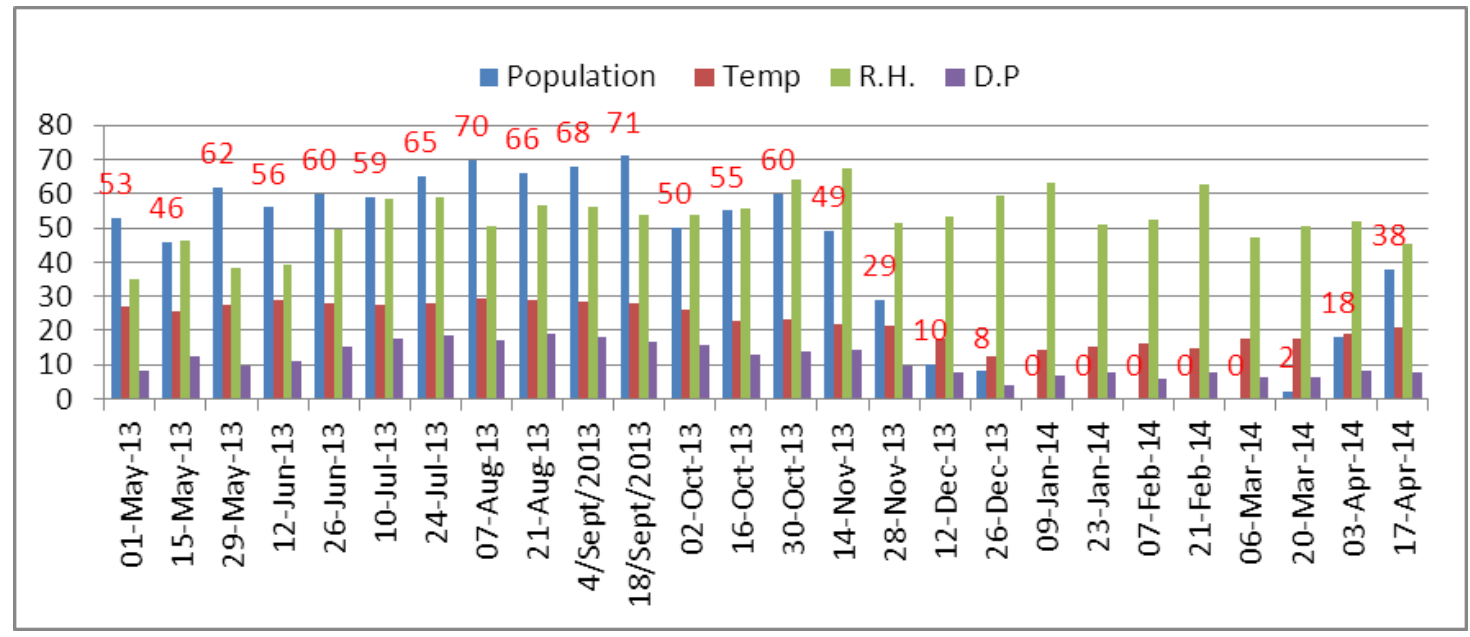

Fig 1 : Effect of air temperature, relative humidity and dew point on larvae population of Phyllocnistis citrella infesting noval orange during 2013 and 2014.

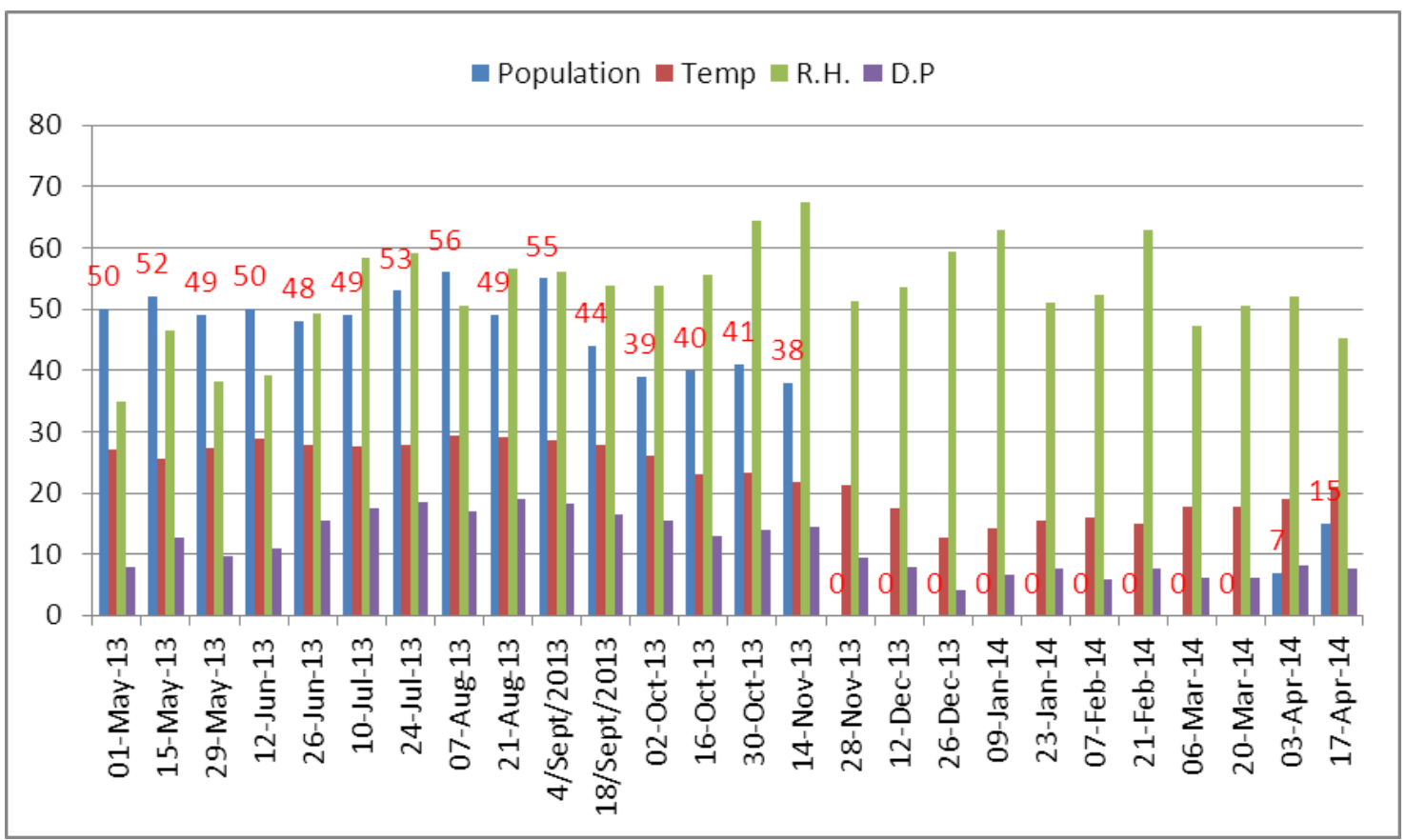

Fig 2 : Effect of air temperature, relative humidity and dew point on larvae population of Phyllocnistis citrella infesting sweet orange during 2013 and 2014. 


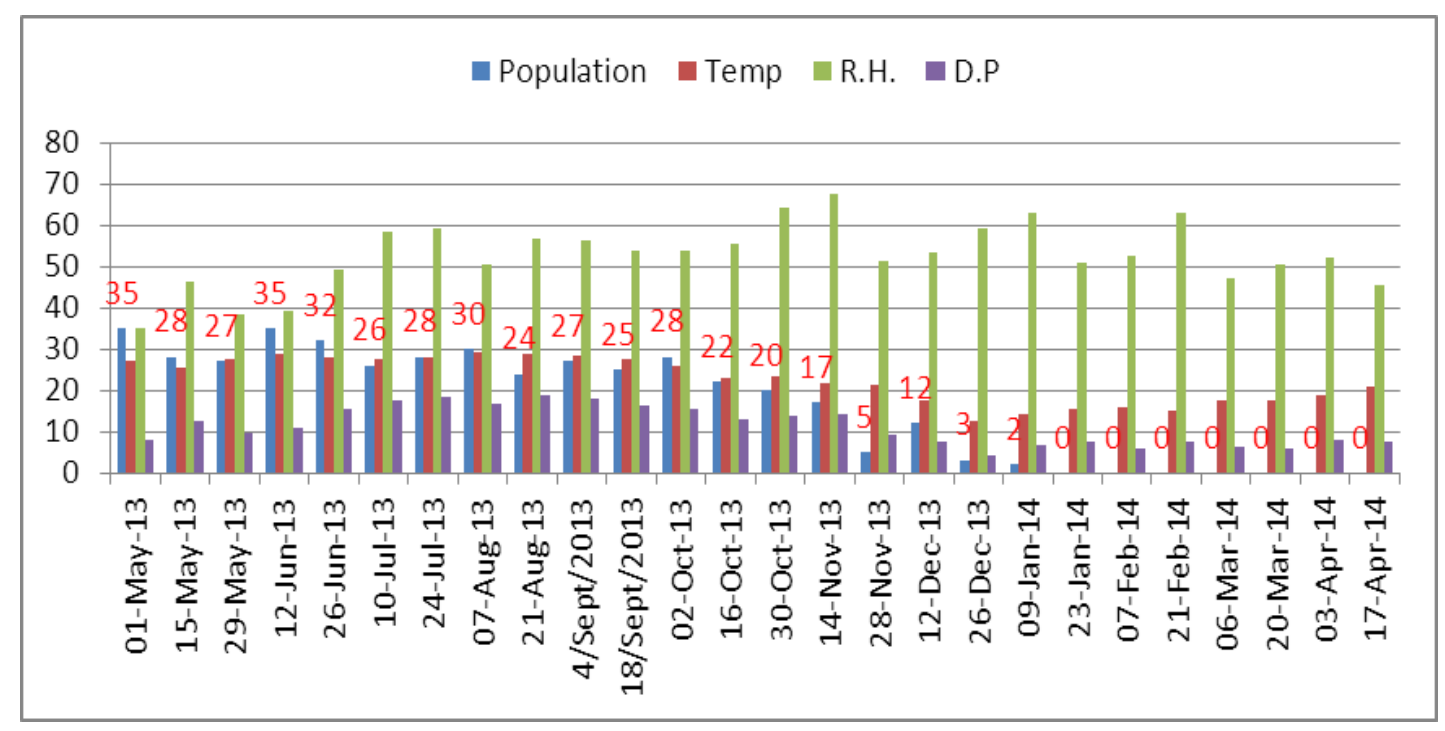

Fig 3 : Effect of air temperature, relative humidity and dew point on larvae population of Phyllocnistis citrella infesting mandarin during 2013 and 2014.

\section{2- Population fluctuation of Phyllocnistis citrella infesting noval, sweet orange and mandarin through 2014 and 2015 months.}

The population fluctuation of Phyllocnistis citrella on noval orange, sweet orange and mandarin were illustrated in Figures ( 4,5 and 6). The population fluctuation of $P$. citrella on noval orange in Fig. ( 4 ) show four peaks. The first, second, third and fourth peak occurred in $29^{\text {th }}$ May, 4 , Sept.,30 Oct. 2014 and 17 Apr. 2015 with total number of $68,85,80$ and 18 larvae /100 leaves at mean temperature, relative humidity and dew point $\left(28^{\circ} \mathrm{C}, 26 \mathrm{RH}\right.$ and 13 DP), ( 30.07, 54.35, and 18.71), (23.57, 50.42 and 12.28) and ( $16.6,73$ and 10.2) respectively .

Results in (Fig. 5) show the population fluctuation $P$. citrella on sweet orange during 2014 and 2015 months. The population recorded 5 peaks, the first, second, third, fourth and fifth peak recording total numbers of $57,60,53,42$, and 11 larvae / 100 leaves at mean temperature, relative humidity and dew point as $\left(28^{\circ} \mathrm{C}, 26 \mathrm{RH}\right.$ and 13 DP), ( 29, 47, and 15), (28.7, 51.85 and 17.42), ( 23.57,50.42 and 12.28) and (16.6, 73 and 10.2), respectively.

Population fluctuation of $P$. citrella infesting mandarin in Fig. ( 6 ) took the same trend as previous mentioned, where population recorded 5 peaks in different periods with different temperature, $\mathrm{RH}$ and DP, where total numbers / 100 leaves were $45,38,47,7$ and 10 larvae on $1^{\text {st }}, 2^{\text {nd }}, 3^{\text {rd }}$, $4^{\text {th }}$ and $5^{\text {th }}$ peak with Temp., RH and DP as (33.85, 53.71 and 17.11), (29.21, 55.64 and 18.78), ( 27.28, 50.5 and 15.78 ), ( 16.14, 63 and 8.71) and (16.6, 73 and 10.2), respectively. Statistical analysis of the results show that there are positive correlation between population of $P$. citrella and each of temperature, relative humidity and dew point. 


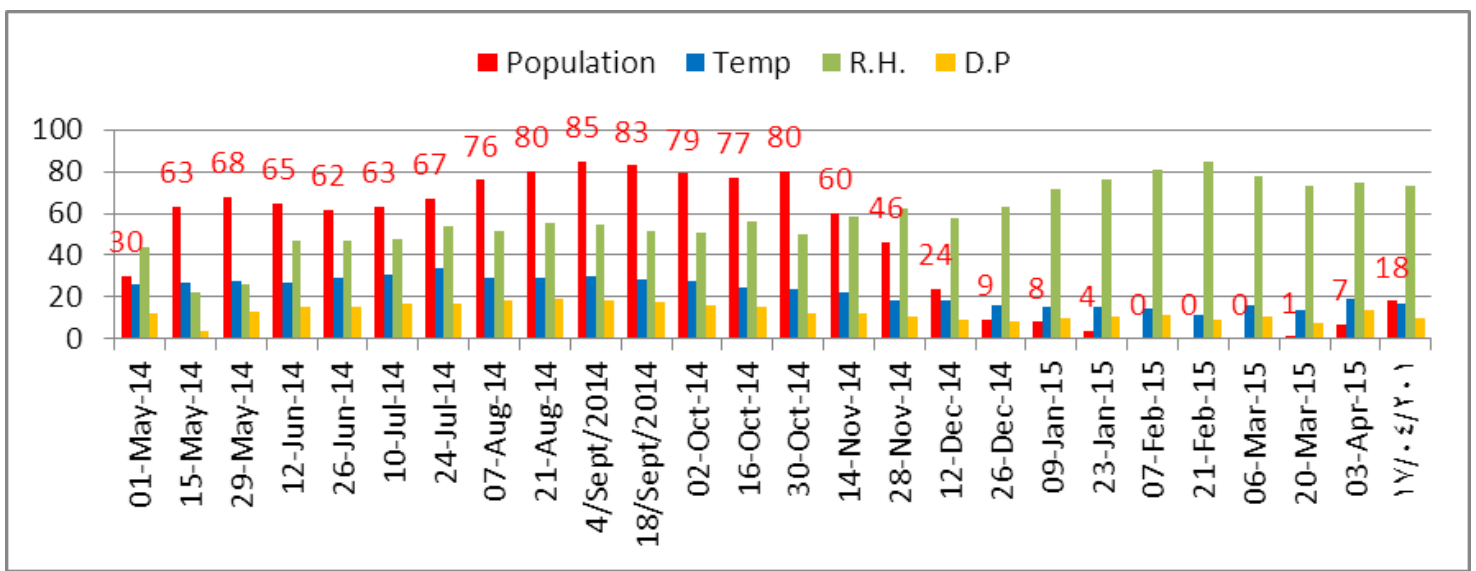

Fig 4 : Effect of air temperature, relative humidity and dew point on larvae population of Phyllocnistis citrella infesting Noval orange during 2014 and 2015 months.

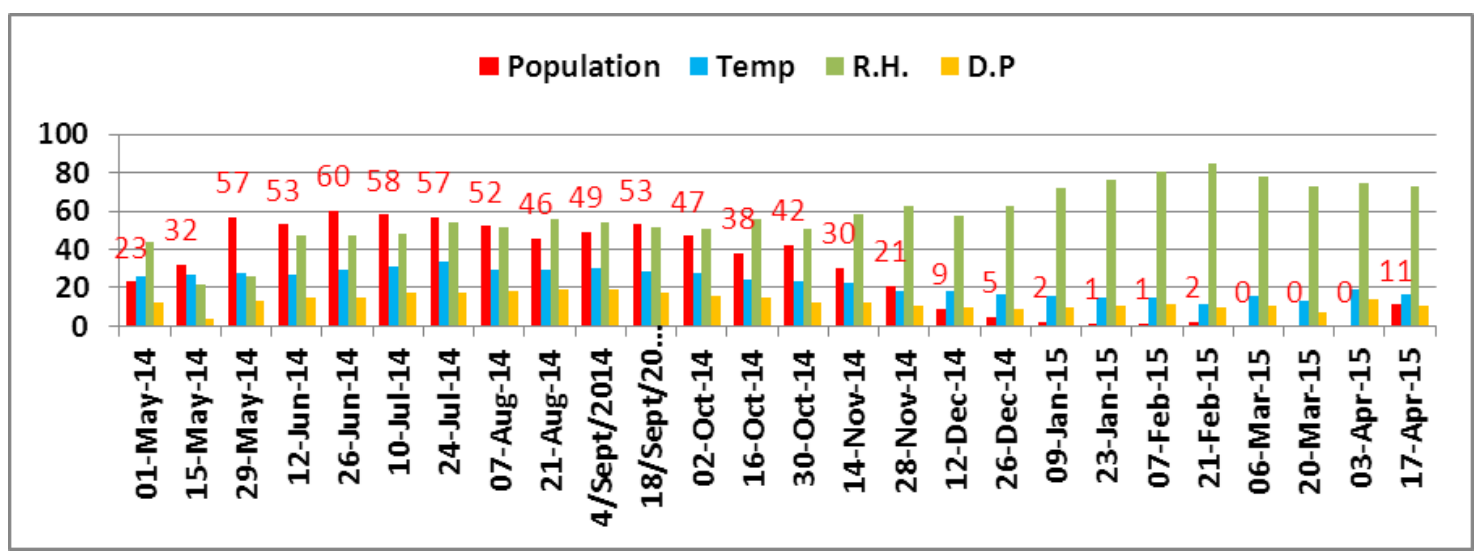

Fig 5 : Effect of air temperature, relative humidity and dew point on larvae population of Phyllocnistis citrella infesting sweet orange during 2014 and 2015 months.

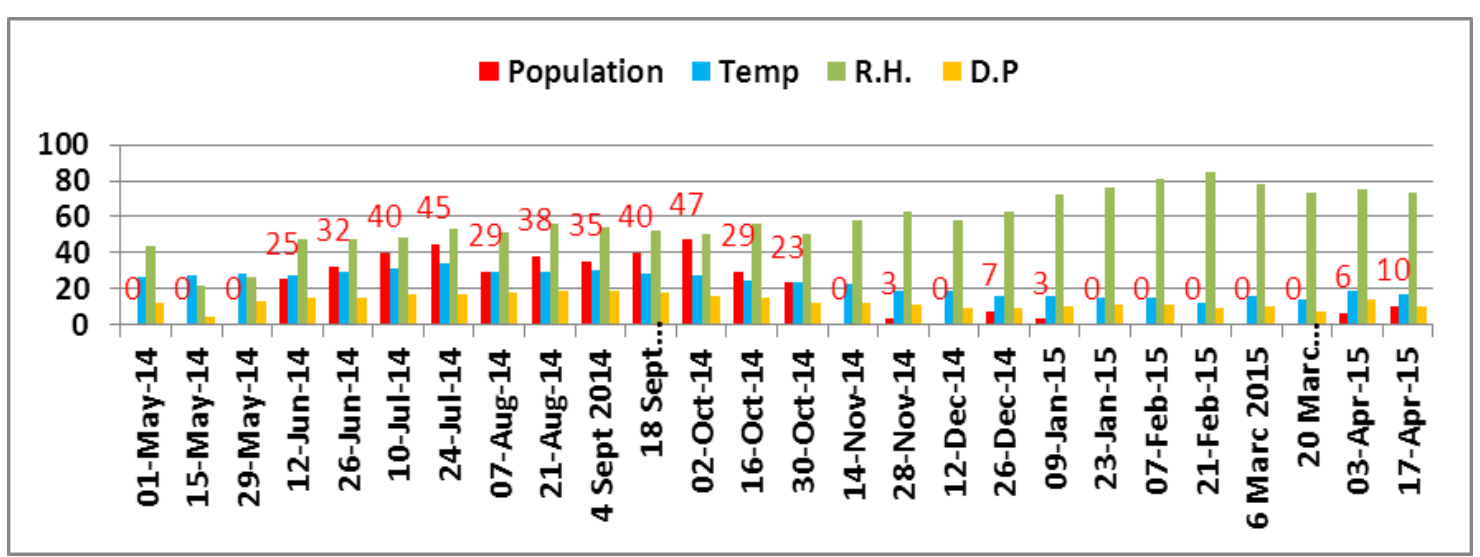

Fig 6 : Effect of air temperature, relative humidity and dew point on larvae population of Phyllocnistis citrella infesting Mandarin during 2014 and 2015 months. 
The larvae population of $P$. citrella increased during summer flushes and declined in the autumn. The most likely reason of the increase and decrease in larvae population was related to both the development of the new flushes and presence of favorable temperature, relative humidity and dew point for the pest development. Besides temperature, relative humidity and dew point there were direct factors which influenced the flushing leaves due to the infestation of citrus trees, where during May to Nov. populations increased, then declined at winter period depending on some environmental factors.

Other reports on the pest population are in agreement with the observations previously described, the seasonal pattern of $P$. citrella was similar with those of (AlKhateeb et al. 1999, Peña et al., 1996; Legaspi et al., 1999, Diez et al., 2006, Hoy et al., 2007 and Güncan et al., 2009) , where population densities was increased from summer to fall and declined during winter.

Also, results of this study showed that $P$. citrella individuals/leaf were more on noval orange than sweet orange and mandarin trees. Similar results have been recorded by Bermudez et al. (2004). The reason for the lower preference of $P$. citrella on mandarin could be owed that mandarins do not develop intense vegetative flushes and consequently the microclimate in their canopy seems to be not ideal for the citrus leafminer compared to other citrus species (Latif and Yunus 1951, FAO 1996).

Moreover, the limited flush during summer and autumn which was observed in mandarin compared to noval and sweet orange trees during this study could be also affect the infestation level from the citrus leafminer. In addition, as pointed out by Knapp et al. (1995) and Jacas et al. (1997), the differences in susceptibility to $P$. citrella among different citrus varieties seem to be related to the tree flushing patterns.

\section{REFERENCES}

Al-Khateeb, N., A. Raie, K. Gazal, F. Shamseen and S. Kattab (1999). A study on population dynamics of citrus leaf miner (Phyllocnistis citrella Stainton) and its parasitoids. Arab. J. Plant Prot. 17: 60-65.

Anagnou-Veroniki, M. (1995). First recordings of citrus leafminer, Phyllocnistis citrella (Stainton) on citrus groves of island Greece. Ann. Inst. Phytopath. Benaki 17:157-160.

Bermudez, EC., NB. Martínez, JV. Graziano, HCA. Bernal and AH. Paniagua. 2004. Phyllocnistis citrella (Lepidoptera: Population fluctuation of Phyllocnistis citrella and its parasitoids in two citrus species in Western Crete (Greece) (PDF Download Available). Available from: Gracillariidae) and its parasitoids in citrus in Ecuador. Fla. Entomol. 87: 10-17.

Clasen, C.P. (1931). Two citrus leafminers of the far east. U. S. Dep. Agric. Tech. Bull.( Washington ), 252. 1-13.

Fletcher, T.B. (1920). Life histories of Indian insects. Microlepidotera. Memoires of Department of Agriculture in India, 6:1217.

FAO. (1996). Report of the workshop on citrus leafminer (Phyl1ocnistis citrella) and its control in the near east. Safita (Syria), 30 September - 3 October 1996: 34.

Garcia-Marí, F., J. Costa-Comelles, R. Vercher and C. Granda (1997). El minador de hojas de citricos: presente y futuro de una plaga importada. Phytoma (España): 94- 102.

Garcia-Mari, F., C. Granda, S. Zaragoza and M. Agusti (2002). Impact of citrus leafminer (Lepidoptera, Gracillariidae) on leaf area development and yield of mature citrus trees in the Mediterranean area. J. Econ. Entomol. 95: 966-974. 
Hoy, MA., R. Nguyen, D. Hall, R. Bullock, M. Pomerinke, J. Peña, H. Browning and P. Stansly (1995). Establishment of citrus leafminer parasitoid Ageniaspis citricola in Florida. Citrus Ind. 76: 12-17.

Jacas, J., A. Garrido, C. Margaix, J. Forner, A. Alcaide and J. Pina (1997). Screening of different citrus rootstocks and citrusrelated species for resistance to Phyllocnistis citrella (Lepidoptera: Gracillariidae). Crop Prot. 16: 701-705.

Knapp, JL., LG. Albrigo, HW. Browning, RC. Bullock, JB. Heppner, DG. Hall, MA. Hoy, R. Nguyen, JE. Peña and PA. Stansly (1995). Citrus Leafminer, Phyllocnistis citrella Stainton: Current Status in Florida. Coop. Ext. Serv., Univ. Florida, Gainesville: 26.

Latif, A. and CM. Yunus (1951). Food plants of citrus leaf miner in Punjab. Bull. Ent. Res. 42: 311-316.

Michelakis, S. (1997). The citrus leafminear status in Greece. IOBC/WPRS Bulletin 20(7): 81-82.
Reinking, O.A. and G.W. Groff (1921). The kao pan seedless Siamese pum melo and its culture. Philippine Journal of science, 19: 389-437.

SAS Institute (2007). J MP version 7.0.1.SAS Institute Inc, Cary, NC.

Sasscer, E.R. (1915). Important insect pests collected on imported nursery stock in 1914. Journal of Economic Entomology, 8: 268-270.

Tsagkarakis, A., A. Kalaitzaki, D. Lykouressis, S. Michelakis and V. Alexandrakis (1999). Presence and impact of introduced and native parasitoids on Phyllocnists citrella Stainton in Greece. IOBC/WPRS Bulletin 22(2): 66.

Uygun, N, NZ. Elekçioğlu, L. Erkiliç, I. Karaca and U. Kersting (2000). Studies on biological control of Phyllocnistis citrella Stainton (Lepidoptera: Gracillariidae) in Turkey. IOBC/WPRS Bulletin 20(7): 96-101. 
تذبذب مجتمع صانعة أنفاق الموالح على ثلاثة أصناف من الموالح

Phyllocnistis citrella (Lepidoptera: Gracillariidae)

هبه محمد النجار ، محمد حسن عبد الرحمن سليمان

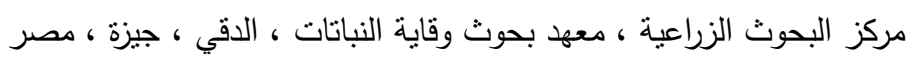

Drmohamedsoliman351@yahoo.com

الملخص العربي

تم إجراء التجربة في مزرعة موالح خاصة في مركز منيا القمح ، محافظة الثرقية ، مصر ، خلال موسمين

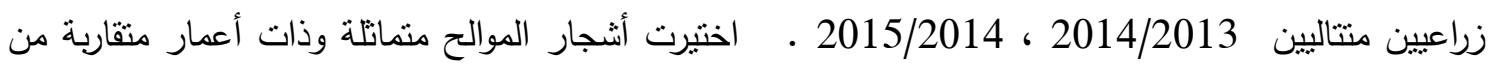

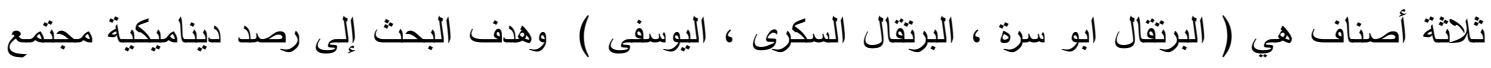

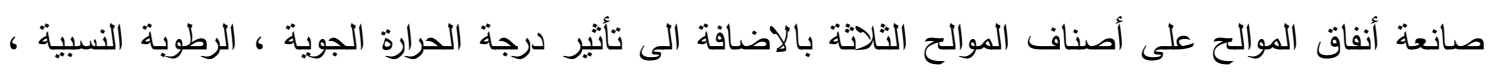

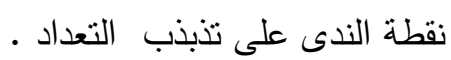

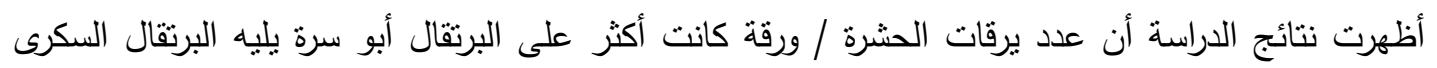

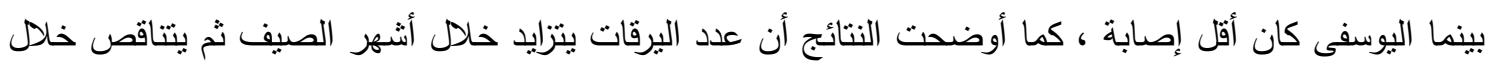

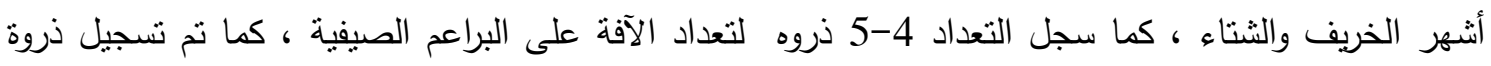

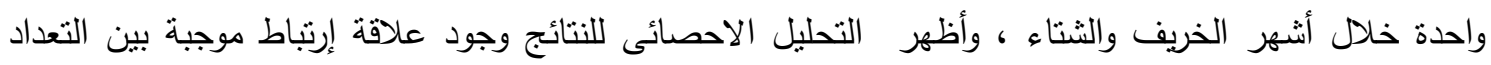
الحشرى للآفة وكل من درجة الحرارة والرطوبة النسبية ونقطة الندى ـ التراء 
Population fluctuation of citrus leafminer, phyllocnistis citrella .................... 